JAMP: Jurnal Adminitrasi dan Manajemen Pendidikan

Volume 4 Nomor 2 Juni 2021, Hal : $95-106$

Tersedia Online di http://journal2.um.ac.id/index.php/jamp/

ISSN 2615-8574 (online)

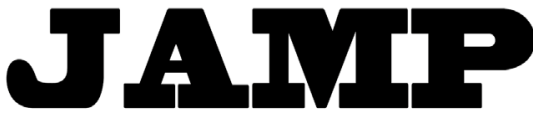

JURNAL ADMINISTRASI DAN MANAJEMEN PENDIDIKAN

\title{
MODERNITAS PESANTREN DITINJAU DARI ASPEK KURIKULUM (Studi Kurikulum Berbasis Minat Bakat)
}

\author{
MUHAMMAD ANGGUNG MANUMANOSO PRASETYO ${ }^{1}$ \\ BASHORI $^{2}$
}

\author{
${ }^{1}$ IAIN Lhokseumawe, Jl. Medan Banda Aceh \\ ${ }^{2}$ UIN Imam Bonjol Padang, Jl. Prof. Mahmud Yunus Lubuk Lintah \\ bashoribashori@gmail.com
}

\begin{abstract}
The bargaining power of pesantren lies in character education, because of the cultivation of character in students of pesantren is by implementing Islamic religious values. Meanwhile, the development in Indonesia continues with a more focused on economics that demands life skills. This research was formulated to develop modernity in some aspects of curriculum in pesantren Sholahuddin Al-Munawwarah Gayo iLues Regency, Aceh Province. The approach to paradigm research is qualitative using the case study method, which is a systematic investigation of ia specific event. Data collected through observation, interviews and documentation. The learning system uses the principles of learning to know, learning to do, learning to be and learning to live together; Implementation of talent interest education by implementing pesantren-based management (MBP); In iaddition, the potential areas around pesantren can be reflected in the delivery of education, in accordance with the principles of contextual education and broad based education; The findings in ithis study produced several main conclusions: (1) reorientation of learning, (2) development of pesantren culture that supports the education of talent-interest, (3) implementation of pesantren based management, (d) synergistic relationships with society, government and talent suppliers.
\end{abstract}

Keywords: Modernity of Pesantren; Curriculum; Talent-Interest.

Abstrak: Daya tawar pesantren terletak pada pendidikan karakter, karena pada dasarnya penanaman karakter pada santri adalah dengan implementas nilai-nilai agama-Islam. Sementara itu, pembangunan di Indonesa terus dilakukan secara bertahap dengan fokus pembangunan yang lebih ditekankan di bidang ekonomi yang menuntut keterampilan hidup. Untuk membentuk lulusan yang berkarakter dan berketeramplan hidup muncul sebuah konsep pendidikan berbasis minat bakat. Penelitian ini dirumuskan untuk mengangkat aspek modernitas pesantren ditinjau dari aspek kurkulum barbasis minat bakat pada pesantren Sholahuddn Al-Munawwarah Kabupaten Gayo Lues Provinsi Aceh. Paradigma pendekatan penelitian adalah kualitatif menggunakan metode studi kasus, yakni penyelidikan sistematis atas suatu kejadian khusus. Data dikumpulkan melalui observasi, wawancara dan dokumentasi. Sistem pembelajaran menggunakan prinsip learning to know, learning to do, learning to be dan learning to live together; Pelaksanaan pendidikan minat bakat dengan menerapkan manajemen berbaiss pesantren (MBP); Selain itu potensi wilayah sekitar pesantren dapat direfleksikan dalam penyelenggaraan pendidikan, sesuai dengan prinsip pendidikan kontekstual dan pendidikan berbasis luas (broad based educaton); Temuan dalam penelitian ini menghasilkan beberapa pokok kesimpulan yaitu: (1) reorientasi pembelajaran berbasis minat bakat, (2) pengembangan budaya pesantren yang menunjang pendidikan minat bakat, (3) implementasi manajemen berbasis pesantren, (d) hubungan kemitraan sinergis dengan masyarakat, pemerintah dan penyalur bakat.

Kata kunci: Modernitas Pesantren; Kurikulum; Minat Bakat. 
Berdasarkan catatan dari Departemen Agama, jumlah pesantren pada tahun 2019 sebanyak 27.722 buah dengan jumlah santri sebanyak 4.173.017 orang (Kementrian Agama, 2019). Jumlah tersebut sangat potensial untuk melahirkan agen perubahan (agent of change) dalam peningkatan indeks pengembangan manusia Indonesia.

Sebagai komponen penting dalam pertumbuhan indeks sumber daya manusia, pesantren memiliki sosio-kultur yang sangat kokoh dalam kehidupan masyarakat. Secara historis pesantren menjadi subkultur dengan keunikan tersendiri dan terpisah dari intervensi pemerintah (Abdurrahman, 2001); (Bashori, 2017a), meski demikian pesantren sebagai institusi kultur yang dalam perkembangannya mulai membuka diri terhadap perubahan zaman dalam bentuk pembaharuan sistem pengelolaan, peningkatan sarana prasarana dan inovasi kurikulum. (Sulthon \& Khusnuridlo, 2006).

Merespon perubahan fenomena tersebut, beberapa pondok pesantren melakukan modernisasi sistem, salah satunya membuka jenjang pendidikan formal seperti SMP, SMA, hingga jenjang perguruan tinggi. Ditinjau aspek transformasi kelembagaan, terdapat jenis pesantren yaitu: (1) pesantren salaf dan (2) pesantren khalaf (Azra, 2000); (Bashori, 2017b). Tipologi pesantren di Aceh sendiri digolongkan menjadi tiga, pesantren salaf; pesantren terpadu -modern-; dan pesantren tahfidz (Dinas Pendidikan Dayah Aceh, 2019).

Daya tawar pesantren terletak pada pendidikan karakter, karena pada dasarnya penanaman karakter pada santri adalah dengan implementasi nila-nilai agama-Islam (Dacholfany, 2014). Aktualisasi nilai tersebut selain terfokus pada pembentukan karakter juga berorientasi pada pendidikan kecakapan hidup (life skill) yang mengacu pada minat bakat para santri. Untuk itu diperlukan modernisasi dalam hal kurikulum pesantren.

Pendidikan pesantren modern tidak hanya bersifat teoretis tetapi pendidikan berbasis praktek -direct method- yang dilaksanakan secara inovatif. Sebagai bagian dari kurikulum pesantren, pendidikan ekstrakurikuler mengambil porsi lebih dibanding jam formal. Program pendidikan minat bakat berbasis pendekatan pendidikan -broad based education- pada dasarnya merupakan dimulai dari perubahan paradigma pendidikan dari pendidikan berorientasi mata pelajaran, kepada pendidikan yang berorientasi pada penguasaan kecakapan hidup (Gogoi, 2018).

Pada sistem pendidikan modern, aspek kemajuan pesantren tidak dilihat dari figur seorang kiai dan santri yang banyak, namun dilihat dari aspek keteraturan administrasi (pengelolaan), misal sedikitnya terlihat dalam pendataan setiap santri yang masuk sekaligus laporan mengenai kemajuan pendidikan semua santri. Selanjutnya kurikulum atau mata pelajaran yang dipelajari terdiri dari berbagai mata pelajaran baik mata pelajaran agama maupun umum. Model sistem pendidikan pesantren modern adalah sistem kelembagaan pesantren yang dikelola secara modern baik dari segi administrasi, sistem pengajaran maupun kurikulumnya (Mukhtar \& Prasetyo, 2020).

Kurikulum pesantren merupakan seperangkat pengalaman belajar yang dirancang untuk santri dalam usaha mencapai tujuan pendidikan pesantren. Untuk itu, diperlukan suatu pola pengelolaan yang memadai, yang disebut dengan manajemen kurikulum. Kurikulum pesantren sendiri terdiri dari kurikulum inti (core curriculum) dan kurikulum pendukung (intra-curriculum). Pemenuhan program kecakapan hidup santri termasuk dalam kurikulum pendukung pesantren.

Output lulusan pesantren ditentukan oleh beberapa faktor determinan yaitu kurikulum dan efektivitas pelaksanaannya. Kurikulum Pendidikan Berbasis Minat Bakat (PBMB) harus sesuai dengan filsafat dan cita-cita bangsa. Kurikulum pesantren merupakan proses pengalaman belajar yang dirancang untuk santri dalam mencapai tujuan pendidikan pesantren (Faj, 2011). Mengingat kurikulum sebagai acuan proses pendidikan dan pengajaran pesantren, kurikulum mesti dipahami secara intensif oleh seluruh komponen masyarakat pesantren, pimpinan, guru, santri.

Rekontruksi sistem pada pondok pesantren tidak semudah melaksanakan pengembangan pendidikan pengajaran di sekolah-sekolah umum. Sebab, dalam konteks status kelembagaan, pimpinan pesantren (Kyai) bukan saja seseorang pemimpin pesantren, tetapi juga sang pemilik pesantren. Otoritas kepemilikan tersebut menghambat pembaharuan serta pengembangan sistem pendidikan dan pengajaran sangat tergantung pada kedudukan sang kyai. Itulah sebabnya hingga saat ini masih terdapat pesantren yang bertahan pada sistem salaf dengan mempraktikkan sistem pendidikan tradisional (Madjid, 1997). 
Problematika lain yang muncul, daya tawar output lulusan tidak cukup dengan bekal keikhlasan dan kesalehan saja, melainkan bekal kecakapan hidup agar dapat hidup mandiri saat mereka terjun dalam kehidupan masyarakat (Ismaya, 2018). Oleh karena tu, mereka perlu dibekali agar tidak canggung dalam bergerak di masyarakat. Untuk menjawab tantangan tersebut pesantren mencanangkan program penerapan keterampilan atau keahlian tertentu seperti usaha pertanian, peternakan, perikanan, pertukangan, koperasi dan lain sebagainya.

Program penerapan keterampilan di pesantren tersebut direspon secara positif oleh pesantren Sholahuddin Al-Munawwarah di Kabupaten Gayo Lues. Respon positf itu dilakukan dengan cara mengakomodasi serta mengadaptasi berbagai hal terutama dalam sistm pendidikan, seperti mulai diterapkannya sistem kurikulum, sistem evaluasi, pengembangan jaringan dan kaderisasi sehingga arah penerapan keterampilan lebih jelas dan terukur. Dalam kurun waktu 3 tahun terakhir beragam prestasi diperoleh Pesantren Sholahuddin dalam konteks kelembagaan maupun kesantrian.

Kemampuan tersebut menjadi nilai tersendiri sehingga peneliti tertarik melakukan penelitan terkait modernisasi pesantren pengembangan kurikulum berbasis minat bakat. Mempertimbangkan kompleksitas kurikulum dalam dunia pendidikan pesantren-biasanya menerapkan lebih dari satu jenis kurikulum-dalam konteks ini Pesantren Sholahuddin mengintegraskan kurikulum KMI dengan kedinasan. Adapun masalah-masalah yang akan dicari jawabannya untuk menjelaskan permasalah penelitian tersebut adalah: (1) bagaimana model kurikulum yang digunakan dan cara penerapan, (2) Dasar pemikiran penerapan kurikulum tersebut, (3) manfaat yang diperoleh dari penerapan model kurikulum, (4) kendala yang dihadapi dalam penerapan kurikulum.

\section{METODE}

Jenis penelitan ini ialah studi kasus, yakni pengusutan sistematis atas suatu peristiwa tertentu untuk menyampaikan penjelasan secara jujur serta akurat perihal kasus tertentu, sehingga memungkinkan pembaca mengetahui apa yg tampak pada sebuah peristiwa serta untuk memeriksa kebenaran analisis dengan meninjau sejumlah data obyektif (Nisbet, V, \& Miner, 2009). Sehingga, kualitatif menjadi pendekatan yang yang tepat dalam penelitian ini.

Metode pengumpulan data dilakukan dengan teknik observasi, wawancara secara mandalam (deep interview), dan dokumentasi. Observasi secara langsung digunakan guna melihat secara komprehenshif berbagai kegiatan proses belajar mengajar dan beragam kegiatan ekstrakurikuler santri. Diantara informan kunci dalam proses wawancara adalah pimpinan pesantren, para pengasuh, guru-guru, pengurus Yayasan dan para santri. Untuk mempermudah wawancara peneliti menggunakan pedoman yang telah disiapkan sebelumnnya. Sedangkan analisis dokumen, peneliti menginterpretasikan berbagai sumber bacaan yang tersedia baik berupa kitab maupun jurnal penelitian (Creswell, 2009). Analisis data beserta interpretasinya dalam penelitian ini melalui beberapa tahap (1) pengumpulan kategori, dengan harapan adanya relevansi hasil dengan isu yang akan muncul; (2) interpretasi langsung; (3) pembentukan pola dengan kategorisasi; (4) pengembangan generalisasi naturalistik melalui analisa data (Huberman \& Miles, 2002) (Bungin, 2018).

\section{HASIL}

\section{Sasaran, lokasi dan Perkembangan Pesantren}

Penelitian ini dilakukan di Pesantren Shalahuddin Al-Munawwarah terletak di Kabupaten Gayo Lues Provinsi Aceh. Sedangkan sasaran penelitian ini akan lebih difokuskan pada model kurikulum berbasis minat bakat di pesantren tersebut. Pesantren ini dipilih sebagai lokas sekaligus sasaran penelitian dengan pertimbangan memenuh syarat sebagai pesantren yang telah melakukan terobosan-terobosan dalam sistem pendidikannya, sehingga dapat dikategorikan sebagaimana konsep yang digunakan dalam penelitan yaitu modernisasi pesantren. 
Aspek modernisasi tidak hanya sebatas perubahan. Akan tetapi lebih dari itu, misalnya, mencakup efisiensi, meningkatnya interaksi antar sesama dan ruangan, dan sangat menjemukannya hubungan sosial (Borgatta \& Borgatta, 1984).

Pada sistem pendidikan yang diimplementasikan di pesantren terkini yakni menyangkut penerapan kurikulum serta metodologi pembelajaran. Modernisasi kurikulum dilakukan menggunakan cara implementasi pendidikan berbasis kecakapan hidup (life skill). Sedangkan pembaruan metodologi yaitu dengan menerapkan sistem klasikal atau penjenjangan. Oleh sebab itu, bentuk lembaga pendidikan madrasah atau sekolah umum serta kelembagaan, fasilitas-fasilitas sebagai suatu kebutuhan. Indikator lain yang menjadi acuan untuk suatu modernisasi dalam sistem pendidikan pesantren ialah aplikasi terhadap sistem informasi dan teknologi seperti jaringan internet dan lain sebagainya.

Demi menjadikan pesantren sebagai lembaga pendidikan Islam unggulan harus mampu bersaing dalam segala hal (Bashori, 2017c). Dalam konteks ini dengan sumber daya manusia yang ada berpotensi dalam hal minat bakat bidang olahraga sepak bola dan seni pencak silat. Melihat realitas tersebut Sholahudidn mencoba mengimplementaskan kurikulum berbasis minat bakat. Perkembangan santri atau siswa baik untuk madrasah tsanawiyah maupun madrasah aliyah lima tahun terakhir mengalami fluktuasi. Fenomena ini sebagai akibat dari berbagai problem yang dihadapi oleh baik pengurus Yayasan sendiri maupun pengurus pesantren. Misalnya untuk penerimaan santri tahun ini, ada perbedaan persepsi antara Ketua Yayasan dengan beberapa pengurus laninya dan pengelola pesantren (madrasah tsanawiyah dan aliyah). Perbedaan itu berkisar pada penetapan status pesantren ke depan, wacana pengurus pesantren berbeda dengan pengurus yayasan.

\section{Konsep dan Model Pendidikan Minat Bakat}

Secara alamiah, setiap anak memiliki sifat yang unik unik, memiliki keragaman indivdu, berbeda satu dengan yang lain dalam berbagai hal, seperti dalam hal intelegensi, bakat, kepribadian, dan kondisi fisik jasmani (Kemdikbud, 2018). Sesuai keragaman karakteristik tersebut, perlu diformulasikan bentuk pendidikan yang dapat mengstimulus perkembangan anak sesuai dengan kebutuhan karakterstiknya. Dalam hal ini, memiliki kemampuan unggul menjadi kebutuhan pendidikan bagi anak. Dalam literature diperoleh beberapa istilah yang melukiskan kemampuan anak-anak berbakat, cerdas, atau cemerlang, yaitu genus, talented, gipted, dan bright atau superior (Suprad, 2004).

Marland dan James J. Gallagher menjelaksn bahwa anak berbakat (gipted or talented child) yaitu "anak yang memiliki kemampuan tinggi dalam aspek intelektual umum, bakat akademik tertentu, kreativitas atau berpikir produktif, leadership, seni pentas, seni rupa dan olahraga (Ohio Gifted Task Force, 2002).

Pesantren telah melakukan berbagai adaptasi dalam pengertian telah melakukan perubahan dan penyesuaian dalam sistem pendidikan, terutama sekali membuka diri terhadap dunia luar seraya memasukkan pengetahuan umum dalam sistem pendidikannya.

Pengimplementasian sebuah konsep pendidikan tentu terkait kondisi siswa serta lingkungannya. Sebagaimana prinsip pendidikan, perangkat kurikulum atau konsep pendidikan wajib mempertimbangkan substansi isi yang dipelajari, karakteristik peserta didik, dan syarat sekolah dan lingkungan yang bersangkutan (Airkunto \& Yuliana, 2008).

Pendidikan berbasis minat bakat merupakan bagian integral dari sistem pendidikan nasional. Melalui kekhususan dalam pelayanan pendidikan, anak memperoleh kesempatan yang maksimal untuk berkembang sesuai dengan potensinya. Apabila setiap anak telah dapat mengaktualsasikan potensinya masing-masnig, pada saatnya mereka akan menjadi seorang manusia yang mandiri, produktif dan kontributif yaitu mampu memberi kontrbusi yang sangat berarti bagi peningkatan kualtias kehidupan bersama. Oleh sebab itu, perangkat pendidikan minat bakat (PMB) dalam setiap jenjang pendidikan tidak dapat dilakukan secara beragam (Prajapati, et al, 2016).

Pendidikan anak berbakat memiliki tujuan yaitu (1) penguasaan sistem konseptual di bidang mata pelajaran; (2) kemampuan mengembangkan keterampilan strategi dalam mengembangkan kemandirian 
dan kreatifitas; (3) kemampuan anak dalam pengembangan suatu kesenangan demi memotivasi belajar yang mampu meningkatkan kerja keras (Galland, 2008).

Secara konseptual dapat dimengerti bahwa PBMB bukanlah sesuatu hal yang baru. Tujuan pendidikan dapat dikaitkan melalui efek pengiring (nurturant effect) yang secara otomatis terbentuk sejalan dengan penguasaan substansi mata pelajaran. Disitulah problem dimulai. Secara pengalaman, menunjukkan bahwa keterampilan proses dan tujuan-tujuan yang bersifat efektif dan perilaku tidak muncul, meskipun siswa dinyatakan telah memiliki kemampuan aspek kognitifnya (Thomas, 2006).

\section{Dasar Pemikiran Pendidikan Berbasis Minat Bakat}

Keterampilan proses yang dimiliki oleh siswa sangat rendah. Ditemukan data di lapanagan bahwa pola pembelajaran yang diberikan di sekolah sangat berorentasi kepada produk. Sehingga kegiatan pembelajaran yang bertujuan untuk menumbuhkan keterampilan proses tidak dilakukan secara maksimal. Dari hasis wawancara dengan beberapa guru ditemukan bahwa kegatan tersebut tidak tercantum dalam perencanaan pembelajaran, sehingga guru merasa tidak perlu melakukannya, apalagi mengukur hasilnya. Hasil penelitian Blazely dkk. (1997) menunjukkan fenomena yang hampir sama, sehingga pembelajaran seakan menjadi penumpukan fakta, konsep dan teori semata sehingga diperlukan variasi proses pendidikan yang tidak monoton atau lebih melibatkan aspek kognitif.

Dalam berbagai sisi, pesantren menerapkan suatu sistem pendidikan terpadu, seperti keterpaduan antara: (1) Teknologi, pendidikan agama, keterampilan, (2) pendidikan formal sekolah dengan nonformal pesantren serta komuntias informal Pesantren, (3) pendidikan intelektual (teori) dengan implementasi penerapan usaha dan kewirausahaan, (4) pendidikan pencapaian prestasipersonal dengan semangat pelayanan pada masyarakat (Haidar, 2005).

Pada awalnya, pengelola pesantren tidak menyadari potensi yang dimilki para santrinya, sehingga dalam even acara tertentu santri tersebut mampu bersaing dan menunjukkan bakat yang menjanjikan. Atas dasar asumsi tersebut pihak pengelola mulai lebih serius dalam memfasilitasii para santrinya, hingga pada akhirnya pendidikan minat bakat masuk dalam kurikulum pesantren.

Sebagai dasar pemikiran paradigma learning for life and school to work dapat dijadkan dasar kegiatan pendidikan, sehingga terjadi hubungan antara pendidikan dengan kebutuhan nyata peserta didik (Scheerens, 2008). Implementasi kurikulum harus diarahkan agar proses pembelajaran berjalan secara efektif, indikatornya dapat diketahui dari pencapaian tujuan oleh santri itu sendiri. Agar tujuan pembelajaran dapat tercapai, para guru perlu didorong oleh kebijakan(Prihantoro, 2015). Secara internal para guru juga perlu memiliki motivasi untuk terus menyempurnakan strategi implementasi kurikulum tersebut.

Memang harus diaku secara tulus bahwa untuk melihat perkembangan secara instan dalam proses pendidikan bukanlah hal yang mudah, tidak segampang membalik telapak tangan sebab harus mempertimbangkan berbagai aspek atau berbagai indikator yang telah ditetapkan atas dasar berbagai teori yang dikemukakan oleh para pakar. Untuk kepentingan itu, diperlukan penelitian secara mendalam tentang model pengembangan pendidikan kecakapan hidup. Sebagai indikator bagamana pesantren mengklasifikasikan kegiatan ekstrakurikuler sebagai sarana peningkatan kecakapan hidup, atau bagaimana pengelola melakukan pembinaan dalam berbagai aspek, untuk kemudan digambarkan dan dijelaskan serta diperbandingkan sehingga dapat digeneralisir.

\section{Manfaat Kurikulum}

Respon pesantren terhadap realitas sosial-tuntutan pasar industri-berupa revisi sistem pengelolaan dalam aspek kurikulum dan manajeral. Akomodasi dan adaptasi tersebut dilakukan pesantren secara total dengan berbagai pertimbangan. Mungkin sikap seperti inilah yang oleh Karel Steenbrink, (1994) disebut dengan istlah "menolak dan mencontoh". Dalam konteks suara tradisional dan konteks pesantren Jawa disebut dengan istlah "menolak sambil mengikut". Mengarahkan santri dari pola pandang konservatif 
menjadi pribadi yang optimis dengan cara-cara hidup dari tradisonal menjadi partispan (Madjid, 2012). Santri tidak hanya bergelut dengan kitab dan teori tetap juga dituntut berolahraga agar selalu sehat.

Pemberdayaan dan modifkasi kurikulum yang dimaksud tercermin dalam konteks perubahan paradigma pembelajaran yang meliput: (1) dari melihat dan menerima ilmu sebagai sesuatu yang formal dan mapan, dirubah menjadi melihat dan menerima ilmu dalam dimensi proses pendidikan, (2) fungsi pendidikan tidak hanya mengasuh dan mengembangkan akal santri, tetap mengolah dan mengembangkan hati nurani serta membekali santri keterampilan hidup (Gogo, 2018). Penyelenggaraan pendidikan selalu diarahkan agar peserta didik: (a) memiliki hidup yang sehat dan berkualitas, (b) memperoleh pengetahuan dan wawasan yang luas, dan (c) memiliki kemampuan memenuhi standar hidupnya menjadi lebih baik lagi (Anwar, 2016).

\section{Implementasi Manajemen Kurikulum Minat Bakat}

Berpijak pada pemikiran tersebut dan melihat Pendidikan Berbasis Miinat Bakat (PBMB) merupakan konsep yang relatif baru, meski sebenarnya merupakan penajaman konsep yang sudah ada sebelumnya, dibutuhkan suatu panduan bagi sekolah untuk melaksanakannya. Pengalaman menunjukkan bahwa suatu inovas pendidikan memerlukan panduan bagi organisasi pelaksana agar dapat menterjemahkan konsep inovasi secara baik, kemudan menerapkannya sesuai dengan konsep yang dimaksud.

Walaupun pelaksanaan PBMB dapat bervariasi, disesuakan dengan kondisi anak dan lingkungannya, namun memiliki prinsp-prinsp umum yang sama. Berikut ini prinsp umum, khususnya yang terkait dengan kebijakan pendidikan di indonesa (Tim Broad Based Education Depdiknas, 2013).

Dalam menerapkan kurikulum minat bakat terdapat beberapa proses yang harus dilakukan, yaitu dengan melakukan serangkaian tes lewat beberapa cara, yaitu: tes prestasi belajar, tes kecerdasan, tes kreativitas, dan nominasi (guru, orang tua, teman sebaya, dan diri sendiri);

Tabel 1: Tahap Implementasi Kurikulum Minat Bakat

\begin{tabular}{ll}
\hline Tes prestasi belajar & $\begin{array}{l}\text { Skematikanya dibuat oleh guru guna mengetahui mata pelajaran tertentu } \\
\text { Bagi murid yang memiliki prestasi unggul berhak dipilih untuk mengikuti } \\
\text { program akselerasi atau pendidikan anak berbakat. }\end{array}$ \\
\hline Tes kecerdasan (intelligensi) & Tes kecedasan ini ada dua macam, yaitu tes personal dan tes kelompok. \\
\hline Tes kreativitas & $\begin{array}{l}\text { Tes ini dilaksanakan secara verbal maupun figural untuk menilai } \\
\text { kemampuan berpikir divergen siswa. }\end{array}$ \\
\hline Observasi & $\begin{array}{l}\text { Tes melalui pengamatan, atau mengamati aktivitas murid sehari-hari, baik } \\
\text { yang bersifat akademik maupun non-akademik. Observasi dilakukan oleh }\end{array}$ \\
& guru, orang tua, atau teman sekelasnya \\
\hline Self-inventory & $\begin{array}{l}\text { Yaitu instrumen yang diberikan kepada murid agar dapat menilai dirinya } \\
\text { sendiri, seperti terkait dengan aspek konsep diri, ambisi, dan aspirasinya. }\end{array}$ \\
\hline Konsultasi dengan orang tua & $\begin{array}{l}\text { Untuk mengetahui anak berbakat dapat diidentifikasi pula melalui orang } \\
\text { tua mereka masing-masing. Aspek-aspek yang ditanyakan kepada orang tua } \\
\text { diantaranya: kemampuan anak, gaya belajarnya, dan minat-minatnya. }\end{array}$ \\
\hline
\end{tabular}

\section{PEMBAHASAN}

Dalam pembahasan ini Pesantren sholahuddin menggunakan metode tes prestasi belajar, tes kreativitas dan observasi. Pelaksanaan PBMB pada santri kelas 1 hngga 3 (jenjang SMP) difokuskan pada kecakapan generik (Generic Life Skill) yang meliputi kesadaran diri atau kecakapan personal (personal skill), dan kecakapan sosial (social sikll). Hal itu didasarkan atas prinsip bahwa GLS merupakan fondasi kecakapan hidup yang akan diperlukan untuk mempelajari kecakapan hidup berikutnya dan bahkan untuk terjun dalam kehidupan sehari-hari, apapun keiinginan seseorang. Pada santri kelas 4 hingga 6 (jenjang SMU) PBMB difokuskan untuk mengembangkan kecakapan akademik dengan juga terus memantapkan GLS. 
Proses implementasi kurikulum berbasis minat bakat juga mencangkup fungsi manajerial, yaitu (1) perencanaan kurikulum terdiri dari beberapa kegiatan termasuk di dalamnya pengembangan silabus, merancang pembelajaran -materi ajar, kategorisasi materi, dan desain visual sajian materi; (2) pelaksanaan kurikulum yang dilakukan oleh guru meliputi penugasan, pemberian tugas tambahan, pembuatan jadwal, pembagian rombongan belajar, absensi kedisiplinan, penetapan kegiatan ekstra kurikulur, pengisian hasil evaluasi pembelajaran, pelaksanaan ujian dan remedial; (3) evaluasi program dengan menunjukkan beberapa hambatan dalam proses implementasi seperti tidak adanya sistem reward punishment, dan komitmen guru.

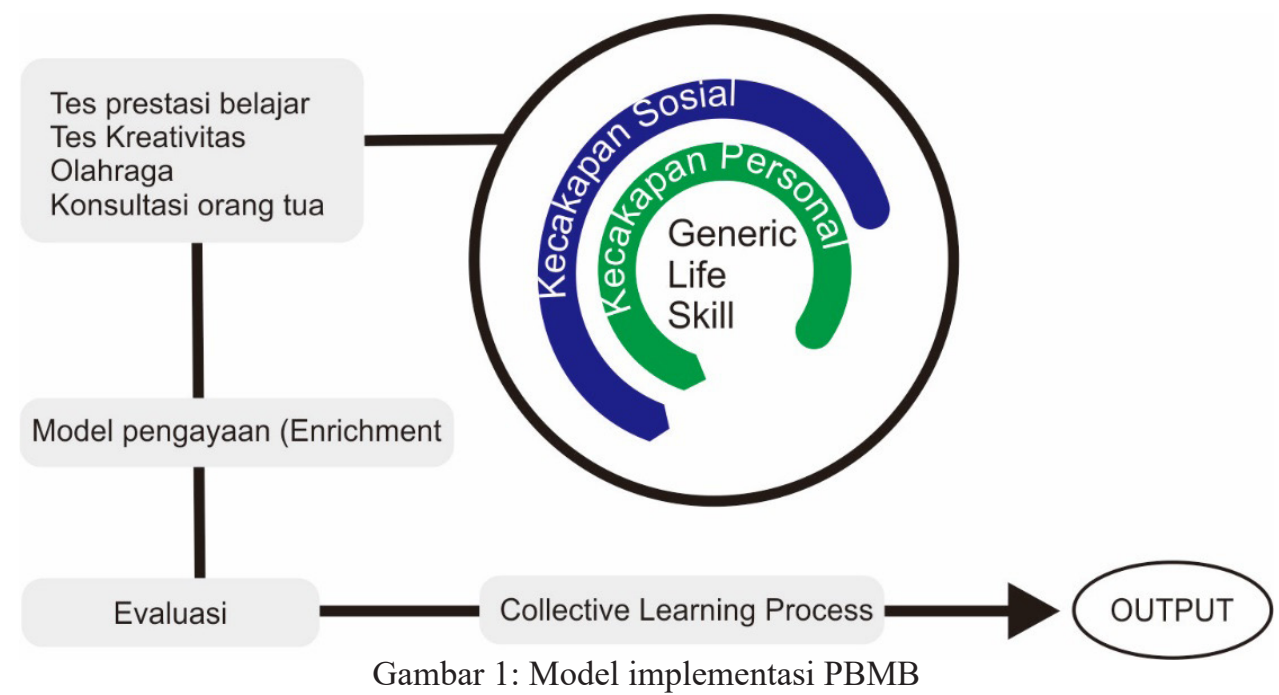

Pihak pengelola juga melakukan program pengayaan, tujuannya untuk melayani para siswa yang memilik kemampuan unggul. Model pengayaan (Enrichment), dilakukan dengan memberikan tugastugas tambahan yang relevan dengan bidang keahlian yang diterimanya. Tugas-tugas tambahan itu, bagi santri yang bergelut di bidang seni silat adalah membaca buku-buku yang isinya relevan dengan silat dan menghafal jurus-jurus yang menjadi ketentuan, selain itu mereka juga diberi pendidikan tentang wasit bela diri. Bagi yang bergelut di bidang olah raga mereka diberikan pelajaran tentang aturan olahraga secara profesional dengan mengerjakan soal-soal tambahan. Model pengayaan ini dapat memenuhi harapan atau kebutuhan santri dalam mengembangkan kemampuan intelektual dan psikologisnya.

Jika PBMB merupakan "penajaman" konsep pembelajaran keterampilan proses dan konsep lainnya, serta pelaksanaannya tidak harus dengan mengubah kurikulum karena kecakapan hidup berhubungan dengan substansi mata pelajaran. Penekanan keduanya tentu tentu berbeda pada setiap jenjang pendidikan sesuai dengan tingkat perkembangan psikologis dan fisologis santri.

Proses implementasi pendidikan minat bakat juga diakhri dengan model evaluasi. Evaluasi adalah suatu cara untuk mengukur dan mengetahui tingkat kemampuan santri. Hasil evaluasi biasanya dituangkan dalam bentuk angka untuk menentukan apakah seorang santri dapat lulus atau naik kelas ke jenjang yang lebih tinggi. Hasil penelitian ini sama halnya dengan hasil penelitian yang dilakukan oleh D. V. Aleksandrov (2019), Rainsberger (2019), dan Wintara (2017).

\section{Metode Pembelajaran}

Pelaksanaan kurikulum menitikberatkan pada praktek. Untuk itu pesantren meniadakan pelajaran siang pada hari rabu untuk diganti menjadi pendidikan minat bakat yang pelaksanaannya di luar kelas. Proses belajar mengajar tersebut dilakukan tanpa penjenjangan kelas dan kurikulum yang ketat, dan biasanya pemisahan jenis kelamin antara laki-laki dan perempuan.

Pembelajaran pendidikan minat bakat dapat dilakukan dalam konsep collective learning process pengarahan secara jamaah dan indvidual learning process dalam membina, memotivasi dan evaluasi 
(Hamalik, 2003). Sebagai tantangan adalah bagaimana melakasanakan evaluasi dengan sistem yang modern, dukungan modernisasi adalah sebuah proses dimana individu berubah dari cara hidup tradisional menuju gaya hidup lebih maju secara teknologi serta cepat terhadap perubaha.

Metode pembelajaran dilakukan dengan beberapa kegiatan: (1) secara teorits kurikulum dan silanbus yang telah disampaikan di ruang kelas, untuk pendidikan agama mengacu pada kurikulum Kementerian Agama dan untuk bidang studi umum mengacu pada kurikulum Pendidikan Nasonal sedangkan untuk bidang minat bakat, baik formal keterampilan mengacu pada kurikulum lokal (kurlok), (2) Secara praktikum dilaksanakan di luar kelas melalui media atau sarana belajar.

Agar pelaksanaan kegiatan belajar mengajar lebih efektif, maka diterapkan metode partisipatif, melalui diskus kelompok, simulasi, ceramah dan tanya-jawab. Partispasi pihak lain dalam hal ini pemerintah terhadap pelaksanaan pendidikan minat bakat di pesantren dalam rangka delegasi, dimaksudkan sebagai ajang penyalur untuk memberikan stimulas agar pesantren Shalahuddin dapat lebih cepat dan sistematis melakukan upaya peningkatan mutu pendidikan sesuai dengan potensi yang dimiliki.

Kegiatan proses belajar mengajar dilakukan dengan mempertimbangkan keterpaduan kurikulum yakni: di satu sisi harus berpartisipasi dalam bidang studi umum, dan sisi lain harus unggul dalam bdang keagamaan serta harus memilik keterampilan dalam bidang pertanian. Dalam rangka itu Pesantren melakulan upaya penyesuaian dan pengembangan strategi belajar mengajar.

Strategi yang dimaksud ialah dalam keseharan, kegiatan Pembelajaran berlangsung sejak selesai shalat subuh (ba'da Subuh) berjamaah di masjid dan dilanjutkan dengan pengajan kitab atau pemberian kosakata maupun ceramah umum yang diikut seluruh santri dari berbagai tingkatan pendidikan. Setelah itu, mereka menuju ke kelas masing-masing guna mengikuti pelajaran di kelas dimula sejak pukul 07.40 11.50 dengan bobot waktu 6 jam pelajaran, kemudian istrahat untuk shalat dzuhur berjamaah di Masjid dan makan siang di dapur umum santri.

Pada pukul 13.20-15.20 dilanjutkan dengan pelajaran di kelas ataupun melakukan praktikum di ruang tertentu sesuai dengan mata pelajarannya, dengan bobot waktu 1 jam pelajaran, hingga tiba shalat ashar. Kegiatan sore hari diisi santri untuk pendidikan minat bakat olahraga dan seni. Khusus hari rabu, jam pelajaran siang diganti untuk pendidikan minat bakat di lapangan. Mereka diberi kesempatan mengikuti kegiatan ekstrakurikuler pilihan seperti: pramuka dan pencak silat (Tapak suci) sebagai ajang minat bakat. Selanjutnya kegiatan harian diakhiri pula di Masjid, setelah para santri melaksanakan serangkaan kegiatan meliputi; shalat maghrib, tadarus Al-Qur'an, shalat isya berjamaah dan dilanjutkan dengan kegiatan di bawah pengawasan Pengurus Organisasi Santri Sholahuddin (ORSADIN), dilanjutkan dengan belajar secara mandiri atau berkelompok.

Pelaksanaan pendidikan minat bakat dapat diterapkan dengan tidak mengubah sistem pendidikan yang berlaku, melainkan pensiasatan kurikulum untuk diorentaskan pada minat dan bakat. Pembelajaran menggunakan prinsip learning to know, learning to do, learning to be dan learning to live together. Pelaksanaan pendidikan minat bakat dengan menerapkan manajemen berbasis pesantren (MBP) merupakan sebuah peluang dengan adanya desentralisasi pendidikan (Prasetyo, 2019a).

Dalam melaksanakan peran pendidikan nonformal, tercatat beberapa pembina dan instruktur yang pernah aktif antara lain Ust. Joned sebagai koordinator bidang pendidikan Olahraga, beliau juga menjabat sebagai wakil pimpinan. Kemudian Ust. Agung Damanik bertindak sebagai koordnator Bidang Silat, beliau juga berposisi sebagai pengurus IPSI perwakilan Gayo Lues.

Keberhasilan pesantren dalam meningkatkan prestasi santrinya sebagai indikator mutu pendidikan pesantren dan jenjang pendidikan pesantren bergantung pada efektifitas implementasi kurikulumnya. Jika kurikulum berjalan efektif maka proses pembelajaran juga akan berlangsung efektif dan prestasi siswa juga mengalami peningkatan secara signifikan. 


\section{Faktor-Faktor yang Mempengaruhi Perkembangan Keberbakatan}

Sesuai hasil penelitian, anak-anak berbakat memilik potensi yang unggul. Potensi ini dapat disebabkan oleh faktor keturunan. U. Branfenbrenner dan Scarr Salaptek mengungkapkan secara tegas bahwa saat ini tidak ada kesangsian mengenai faktor genetika mempunya andil yang cukup besar terhadap kemampuan mental seseorang (Schwartz, 1997).

Dalam proses perkembangannya, bakat anak memerlukan sentuhan dari lingkungan, baik perawatan, pengasuhan, dan pendidikan. Sehingga perkembangangan bakat anak dapat dipengaruhi oleh lingkungan sekitar. Melalui lingkungan, anak memperoleh apa yang dibutuhkannya, termasuk di sana ada berbagai peluang yang mendukung teraktualisasikan potensi yang dimilikinya.

Tantangan lain yang harus dihadapi Sholahuddin berasal dari orangtua murid/wali santri yang tidak siap melihat anaknya berwiraswasta setelah selesai dari pesantren. Mayoritas wali santri masih terjebak dalam pola pikir konservatif, bahwa tamat pendidikan mejadi pegawai atau tentara. Wali santri demikian, bukan merupakan lingkungan yang cocok dan kondusif bagi perkembangan pesantren. Disorentasi tersebut tanpa langkah antisipatif ditanamkan di pesantren. Masalahnya, Darul Amin tidak cukup kuat untuk merubah budaya dan jalan pikiran orang tua dan masyarakat yang demikan. Tantangantantangan tersebut di atas lebih bersifat eksternal, sedangkan tantangan internal yang dihadap dan sangat menggangu adalah konflik internal khususnnya datang dari Pengelola Pesantren serta beberapa pengurus Pesantren. Konflik internal terjadi akibat keinginan perubahan kebijakan pesantren.

\section{Kemitraan Strategis}

Prinsip pendidikan kontekstual dan pendidikan berbasis luas (broad based education) dapat direfleksikan melalui penyelenggaraan potensi wilayah sekitar. Oleh karena itu, pesantren membuka diri terhadap akses peningkatan pendidikan minat bakat. Bahkan dalam dua tahun terakhir beberapa orang guru pesantren dipercaya pemerintah Gayo Lues sebagai staf khusus bidang olahraga yang memudahkan akses dalam pemanfaatan fasilitas untuk latihan dan evaluasi. Di bidang silat, seorang guru sudah berstatus pendekar dan dipercaya sebagai koordinator lomba dalam even regional hingga nasional.

Dalam rangka apresiasi terhadap prestasi yang berhasil di raih dalam bidang olahraga dan seni pencak silat, koordinator pelaksana kegiatan yang berstatus guru Shalahuddin juga mulai Pendidikan nonformal dalam bentuk pendidikan latihan (Diklat), bukan santri pada program pendidikan formal. Penyelenggaraan diklat dilaksanakan dengan sponsor yang bervariasi antara lain: (1) Dinas Pendidikan Pemuda dan Olahraga; (2) kerjasama dengan ikatan Persatuan Silat indonesia (PS) atau organisasi sosial lainnya, (3) kerjasama dalam lingkungan pesantren seindonesia.

Pendidikan nonformal yang telah dilaksanakan antara lain; (1) orientasi keolahragaan dan diklat kepemimpinan, (2) mengikuti berbagai macam event pertandingan yang linear dengan program minat bakat pesantren (olahraga dan silat), (3) pengajian di Majels Ta'lim secara bulanan, dan(4) pengembangan masyarakat jarak jauh dilakukan bekerjasama dengan mitra kerja Sponsorship.

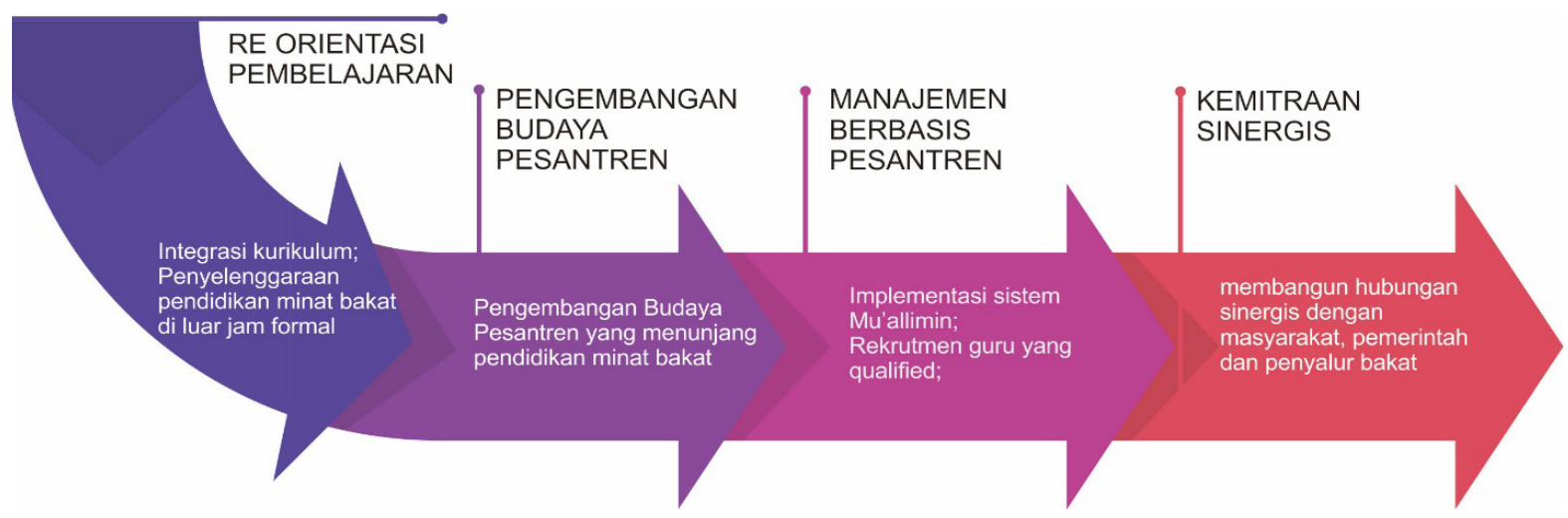

Gambar 2: Novelty Penelitian 
Secara teknis, pelaksanaan pendidikan minat bakat di pesantren dapat dilaksanakan melalui lima cara, yaitu: (1) reorientasi pembelajaran, (2) pengembangan budaya pesantren yang menunjang pendidikan minat bakat, (3) implementasi manajemen berbasis pesantren, (d) membangun hubungan sinergis dengan masyarakat, pemerintah dan penyalur bakat.

Penyelenggaraan pendidikan selalu diarahkan agar peserta didik menuju hidup yang sehat dan berkualitas sebagai tujuan penyelenggaraan pendidikan, selin juga mendapatkan pengetahuan dan wawasan yang luas, serta memiliki akses untuk mampu memenuhi standar hidupnya secara layak. Sistem pembelajaran menggunakan prinsip learning to know, learning to do, learning to be dan learning to live together.

Proses implementasi kurikulum di pesantren mesti dilaksanakan secara kolaboratif. Komponen penting seperti Direktur KMI, Staf Pengajaran, Kepala Sekolah berpartisipasi dalam semua tahap pengelolaan kurikulum. Bentuk partisipasi dapat memupuk rasa kebersamaan sehingga para guru dan santri memiliki perasaan ikut memiliki (sense of belonging) sehingga mampu memberikan dorongan kepada coordinator pelaksana dalam mencapai tujuan yang telah disepakati.

Sebagai pelaksana jenjang pendidikan formal realitas pengembangan kurikulum, pembelajaran, dan tradisi akademik di pesantren sholahuddin sudah berdasarkan standar akreditasi sekolah / madrasah di Indonesia. Temuan dari penelitian juga menunjukkan bahwa pesantren secara umum telah memenuhi standar pengembangan kurikulum dalam hal mekanisme, kelengkapan arsip dokumen serta pelibaan eksternal organisasi dalam pengembangannya. Pada aspek perencanaan, pesantren memiliki dokumen pembelajaran sesuai dengan beban kelompok belajar secara umum dan telah memenuhi standar. Pendidikan berbasis minat bakat secara umum dilaksanakan dengan baik terbukti dari prestasi yang dicapai baik secara individu maupun organisasi.

Efektivitas implementasi program terlihat dari terciptanya suasana akademik yang mendukung, dalam hal (1) mengkondisikan para santri menjadi pembelajar sejati seumur hidup dengan keahlian yang dimiliki; (2) pendidikan berbasis minat bakat mampu meningkatkan keterampilan siswa untuk berpikir kreatif, inovatif, produktif, dan kritis; (3) inovasi yang dilaksanakan pada proses penerapan dan pendekatan saintifik seperti study tour, seminar, demonstrasi, dan keterlibatan dalam berbagai even; dan (4) para santri dituntut pada miliu yang kondusif, yaitu memperkuat keterampilan santri untuk bertindak secara individu, kolaboratif, dan komunikatif.

Diantara kelebihan tersebut masih terdapat kelemahan. Melalui analisis hasil penelitian dapat diidentifikasi kelemahan tersebut terletak pada aspek pengembangan sumber belajar, sarana prasarana, dan model pendekatan. Beberapa hasil penelitian yang mendukung temuan penelitian, seperti yang diungkapkan Lena (2020) strategi pendidikan minat bakat mengacu pada pemahaman peserta didik, Ortiz, López-Martínez, \& Berná, (2020) pemberian materi minat bakat secara integratif ke dalam materi pembelajaran; dan pendidikan minat bakat merupakan salah satu instrumen pembentuk karakter (Roosandriantini, 2020); dan peningkatan kualitas output pendidikan (Prasetyo, 2019b).

Perubahan dalam aspek kehidupan akan membawa perubahan setiap dimensi sosial. Tidak terkecuali aspek lembaga pendidikan. Tuntutan dan kebutuhan menuntut segala lembaga pendidikan mampu adaptif dengan persaingan yang ada. Oleh sebab itu, modernitas pesantren membawa perubahan baru di dunia pendidikan Islam dalam meramu segala kebutuhan pendidikan yang didambakan oleh masyarakat. Agar tujuan program minat bakat dapat tercapai, pengembangan kurikulum harus dilakukan secara sistematis, dan mencakup komponen yang saling berkaitan dalam mencapai kompetensi dasar yang telah ditetapkan.

Hasil penelitian ini memberikan implikasi pemahaman bagaimana lembaga pendidikan pesantren ikut serta dalam reorientasi pengembangan kurikulum. Pesantren dalam hal pengembangkan konsep minat bakat santri menghasilkan lembaga pendidikan yang bermutu. Dalam konteks penelitian lebih lanjut, konsep modernitas lembaga pendidikan Islam sangat relevan dikaji sesuai dengan relevansi keilmuan para peneliti. Dengan begitu akan menghasilkan hasil penelitian yang beragam dalam konteks keilmuan yang beragam pula baik sosial humaniora maupun sains dan teknologi. 


\section{KESIMPULAN}

Pesantren Sholahuddin merupakan pesantren dengan sistem KMI, aspek modernitas pesantren ditunjukkan lewat revitalisasi kurikulum guna memfasilitasi bakat santri. Adapun strategi yang dilakukan pihak pengelola pesantren dalam pelaksanaan pendidikan minat bakat tidak dengan mengubah sistem pendidikan yang berlaku, melainkan pensiasatan kurikulum untuk diorentaskan pada minat dan bakat. Pelaksanaan pendidikan minat bakat dengan menerapkan manajemen berbasis pesantren (MBP); Selain itu potensi wilayah sekitar pesantren dapat direfleksikan dalam penyelenggaraan pendidikan, sesuai dengan prinsip pendidikan kontekstual dan pendidikan berbasis luas (broad based education). Proses pelaksanaan pendidikan minat bakat di pesantren dapat dilaksanakan melalui lima cara, yaitu: (1) reorientasi pembelajaran, (2) pengembangan budaya pesantren yang menunjang pendidikan minat bakat, (3) implementasi manajemen berbasis pesantren, (d) membangun hubungan sinergis dengan masyarakat, pemerintah dan penyalur bakat.

\section{DAFTAR RUJUKAN}

Abdurrahman, W. (2001). Menggerakkan Tradisi Esai-Esai Pesantren. Yogyakarta: LKiS.

Anwar. (2016). Buku Pendidikan Kecakapan Hidup (Life Skill Education). Bandung: Alfabeta.

Arikunto, S., \& Yuliana, L. (2008). Manajemen Pendidikan (4th ed.). Yogyakarta: Aditya Media.

Azra, A. (2000). Pendidikan Islam Tradisi dan Modernisasi Menuju Milenium Baru. Jakarta: Logos.

Bashori. (2017a). Modernisasi Lembaga Pendidikan Pesantren Perspektif Azyumardi Azra. Nadwa, 11(2), 269. https://doi.org/10.21580/nw.2017.11.2.1881

Bashori, B. (2017b). Modernisasi Lembaga Pendidikan Pesantren. Jurnal Ilmu Sosial Mamangan, 6(1), 47. https:// doi.org/10.22202/mamangan.1313

Bashori, B. (2017c). Paradigma Baru Pendidikan Islam (Konsep Pendidikan Hadhari). Jurnal Penelitian, 11(1), 141.

Borgatta, E. F., \& Borgatta, M. L. (1984). Encyclopedia of Sociology. New York: Macmillan Publishing Company.

Bungin, M. B. (2018). Penelitian Kualitatif, Komunikasi, Ekonomi, Kebijakan Publik, dan Ilmu Sosial Lainnya, Edisi Kedua. Jakarta: Kencana Prenada Media Grup.

Creswell, J. W. (2009). Research Design: Qualitative, Quantitative, and Mixed Methods Approaches. California: Sage Publication Inc.

D. V. Aleksandrov. (2019). Philosophical-Anthropological Receptions Of Educational Interest Of Student Youth. Humanitarian Paradigm, (1), 28-33. https://doi.org/10.33842/2663-5186/2018/1/1/28/33

Dacholfany, M. I. (2014). Pendidikan Karakter Belajar Ala Pesantren Gontor (1st ed.). Jakarta: Wafi Media Tama.

Dinas Pendidikan Dayah Aceh. (2019). Rencana Kerja Dinas Dayah 2019. Banda Aceh.

Faj, A. (2011). Manajemen Pendidikan Pesantren Dalam Perspektif Dr. KH. Abdullah Syukri Zarkasyi, M.A. Jurnal At-Ta'dib.

Galland, C. (2008). Effective Teacher Leadership: A Quantitative Study of The Relationship Between School Structures and Effective Teacher Leaders. University of Missouri Columbia United States.

Gogoi, S. (2018). Life Skill Education in School for Sustainable Human Development. Advance Research Journal of Social Science, 9, 114-118. https://doi.org/10.15740/HAS/ARJSS/9.1/114-118

Hadari, A. (2005). Panorama Pesantren dalam Cakrawala Modern. Jakarta: Diva Pustaka.

Hamalik, O. (2003). Perencanaan Pengajaran, Berdasarkan Pendekatan Sistem (1st ed.). Jakarta: Bumi Aksara.

Huberman, M., \& Miles, M. B. (2002). The Qualitative Researcher's Companion. Sage.

Ismaya, S. (2018). Pengaruh Kemandirian Pribadi, Ekspektasi Pendapatan, dan Pendidikan Kewirausahaan Siswa Muslim di UPT Pelatihan Kerja Tulungagung.

Kemdikbud. (2018). Kembangkan Bakat dan Minat Siswa dalam Penguatan Pendidikan Karakter. Retrieved from https://gln.kemdikbud.go.id/

Kementrian Agama. (2019). Data Pondok Pesantren. Retrieved from Pangkalan Data Pondok Pesantren website: https://ditpdpontren.kemenag.go.id/pdpp/statistik?id=11

Lena, I. M., Anggraini, I. A., Utami, W. D., \& Rahma, S. B. (2020). Analisis Minat dan Bakat Peserta Didik terhadap Pembelajaran. TERAMPIL: Jurnal Pendidikan Dan Pembelajaran Dasar, 7(1), 23-28.

Madjid, N. (1997). Bilik-Bilik Pesantren Scbuah Potret Perjalanan. Jakarta: Paramadina. 
Madjid, N. (2012). Modernisasi Pesantren (Kritik Nurcholis Terhadap Pendidikan Islam Tradisional). Jakarta: Ciputat Press.

Mukhtar, H., \& Prasetyo, M. A. M. (2020). Pesantren Efektif Model Teori Integratif Kepemimpinan-KomunikasiKonflik Organisasi. Deepublish.

Nisbet, R., IV, J. E., \& Miner, G. (2009). Handbook of Statistical Analysis and Data Mining Applications. New Jersey: Elsevier Science.

Ohio Gifted Task Force. (2002). Gified in the 21 1st Century (A Report of F indings and Recommendations).

Ortiz, A. F. H., López-Martínez, O., \& Berná, F. J. C. (2020). Creative Talent and Personality: A Primary Education Study. Sustainability, 12(10), 1-11.

Prajapati, R., Sharma, B., \& Sharma, D. (2016). Significance of Life Skills Education. Contemporary Issues in Education Research (CIER), 10(1), 1-6. https://doi.org/10.19030/cier.v10i1.9875

Prasetyo, M. A. M. (2019a). Pengaruh Kepemimpinan Transformasional dan Budaya Organisasi Terhadap Pengelolaan Pendidikan Kecakapan Hidup di Ponpes Sholahuddin Al-Munawarah Gayo Lues. Ziryab: Jurnal Pendidikan Islam, 1(1), 90-104.

Prasetyo, M. A. M. (2019b). Sistem Pasar Output Pendidikan Islam. At-Ta'dib: Jurnal Ilmiah Prodi Pendidikan Agama Islam, 10(2), 136-153.

Prihantoro, C. R. (2015). The Perspective of Curriculum in Indonesia on Environmental Education. International Journal of Research Studies in Education, 4(1), 77-83.

Rainsberger, R. (2019). Understand 'legitimate educational interest' under FERPA. Campus Legal Advisor, 19, 6--6. https://doi.org/19. 6-6. 10.1002/cala.30974

Roosandriantini, J., \& Tiorma, S. D. T. D. (2020). Pengembangan Bakat Minat dan Pendidikan Karakter di UPTD “Kampung Anak Negeri” Surabaya. ASAWIKA: Media Sosialisasi Abdimas Widya Karya, 5(01), 1-5.

Scheerens, J. (2008). Improving School Effectiveness. Retrieved from http://www.unesco.org/ iiep.

Schwartz, W. (1997). Strategies for Identifying the Talents of Diverse Students. New York: ERIC/ CUE Digest.

Steenbrink, K. (1994). Pesantren, Madrasah, Sekolah Pendidikan Islam DaIam Kurikulum Modern. Jakarta: LP3ES.

Sulthon, M., \& Khusnuridlo. (2006). Manajemen Pondok Pesantren dalam Perspektif Global (1 st ed.). Yogyakarta: Laksbang PressIndo.

Supriadi, D. (2004). Perspektif Psikologis dan Sosial Pendidikan Anak-anak Berbakat. Bandung: Remaja Rosda Karya.

Thomas, G. (2006). Life Skill Education and Curriculum. Shipra Publications.

Tim Broad Based Education Depdiknas. (2013). SD SMP SMA Kecakapan Hidup (Life Skill). Semarang: CV. Bumi Pustaka.

Wintara, I. M. S. (2017). Pentingnya Peran Guru dalam Pengembangan Minat, Bakat dan Kreativitas Siswa Melalui Ekstrakurikuler. Pendidikan Guru Sekolah Dasar, 3. 